\title{
Regional factors of sustainable development of small and medium-sized businesses
}

\author{
Erik Avanesian ${ }^{1 *}$ and Jose $\mathrm{Nino}^{2}$ \\ ${ }^{1}$ Ural State University of Economics, 8 Marta Str. 62, 620144 Ekaterinburg, Russia \\ ${ }^{2}$ EAN University, Calle 719-84, Bogota, Colombia
}

\begin{abstract}
The small and medium-sized business sector, on the one hand, plays a crucial role in the development of any region, providing the consumer market with basic goods and services, creating jobs, at the same time diversifying risks in economic development. On the other hand, the sustainability of the functioning of the small and medium-sized enterprise sector largely depends not only on national, but also on regional factors. The article examines the regional factors of development of small and medium-sized businesses. It has been found that there is no generally accepted classification of regional reasons determining the degree of sustainability of small and medium-sized enterprises. The author proposes and substantiates regional sustainability factors influencing the functioning of SMEs: economic and geographical location, the system of regional support for small and medium-sized businesses, the level of consumer demand and purchasing power. This study will make it possible to apply the successful experience of SMEs in the context of regional development, based on the key, but not exhaustive factors identified in this study.
\end{abstract}

\section{Introduction}

The successful functioning of small and medium-sized enterprises (SMEs) is directly related to the sustainability of the development of a particular region. According to the data of Rosstat, the share of small and medium-sized businesses in the country's GDP in 2019 was $22.9 \%$. At the same time, in the countries with advanced economies, the number of small and medium-sized enterprises is over $80 \%$ of the total number of enterprises. This sector occupies $2 / 3$ of the economically active population, where more than half of GDP is produced. SMEs are the most important trigger of the competitiveness in the market economy of both the country as a whole and the regions it includes. This is due to the fact that SMEs are able to quickly adapt to the economic transformations taking place in the country, despite the possible difficulties associated with the lack of information about changes in the market [1]; promote the introduction of innovations and new technologies along with large enterprises, create jobs, which directly proportionally affects the growth of

\footnotetext{
*Corresponding author: avanesyan2013@mail.ua
} 
employment of the population, and, accordingly, the increase in the regional rating. The stability of the regions is determined by such indicators as the index of business activity, innovation activity, scientific and technological development of the constituent entities of the Russian Federation, which include a number of small and medium-sized enterprises with an appropriate density of distribution, branch specialization, the size of companies and the number of relationships, various schemes of interaction with government representatives., suppliers and business partners, investors and the consumer market [2]. These indicators are not exhaustive, however, in addition to the system of indicators characterizing the development of the region, it is worth highlighting the factors of sustainable development of small and medium-sized businesses, which determine the totality of the quantitative and qualitative dynamics of the development of the region. Besides, the factors can both potentiate and discourage the sustainability of SME development [3-5]. Thus, the need to ensure the sustainability of the development of small and medium-sized enterprises requires a comprehensive study of regional factors within the framework of the definition and systematization of which it is possible to determine the regional sustainability factors affecting the efficiency of the functioning of SMEs, relevant for the analysis of any region of our country. In the Russian and foreign scientific literature there is no unified classification of factors of sustainability of the development of small and medium-sized businesses, which would be approved at the regional level.

In this study, we will understand the sustainable development of SMEs as a complex process determined by the factors of social and economic nature, which are the basis for the formation of an integral system of connections, relations and interactions [6].

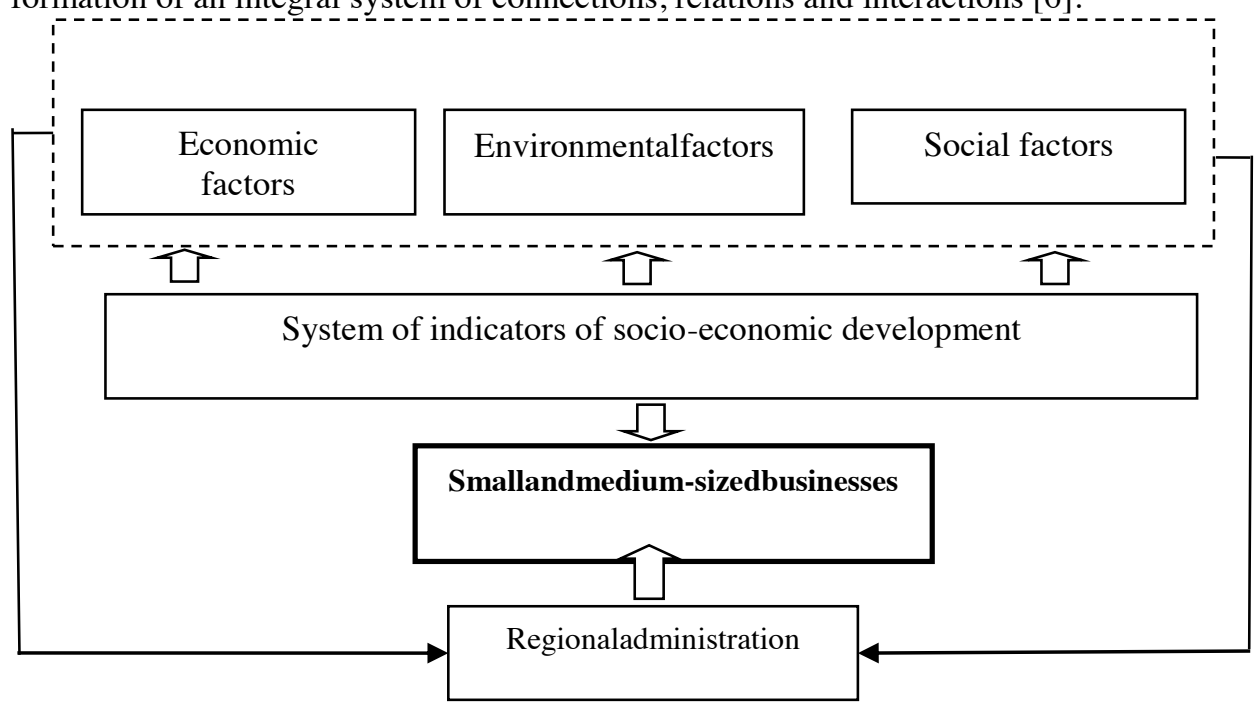

Fig. 1.Structural diagram of the influence of medium and small enterprises on the development of the region

The diagram given above shows that the set of regional factors (economic, social, environmental) that determine the sustainability of the functioning of small and mediumsized enterprises has a certain system of indicators, with the help of which it is possible to track the level of development of SMEs in a particular region, taking into account industry affiliation, development potential in a competitive environment.

\section{Materials and methods}


The materials of this study are the National Project "Small and Medium-Sized Businesses and Support for Individual Entrepreneurial Initiatives", the Strategy for the Development of Small and Medium-Sized Businesses in Russia until 2030, various state and regional programs for supporting SMEs, the Federal State Statistics Service; local and foreign scientific literature.

When writing the article, the following methods were used: methods of analysis (including statistical analysis), synthesis, generalization and systems approach, classification, deductive method, analogy, formalization, abstract-logical method for theoretical generalizations and formulating conclusions and scientific understanding.

\section{Results and discussion}

In modern scientific literature, you can find a lot of different approaches to the classification of factors influencing the development of small and medium-sized businesses. It should be noted that in the context of our study, it is necessary to identify factors that include criteria, conditions for ensuring the sustainability of SME development at the regional level. One of these attempts can be seen in the study of M.O. Podprugin, where, according to the author, the provision of sustainable development of the region, including the effective work of small and medium-sized businesses, occurs due to the balance of factors of socio-economic and natural-ecological development. Thus, such groups of factors as economic, financial and economic, industrial and production, the level of infrastructure development, food security of the region, regional marketing, the level of development of the social sphere are distinguished [7]. These factors can be applied for the assessment of the region as a whole, and therefore it is necessary to focus on the driving forces affecting the sustainability of SMEs in order to determine the relationship with the level of development of the region. In some sources the factors hindering the development of small and medium-sized enterprises are highlighted; in others - those that contribute to their effective functioning. For example, according to the Strategy for the Development of Small and Medium-Sized Businesses in the Russian Federation for the period up to 2030, factors that have had a negative impact on SMEs are highlighted. They include: an increase in interest rates, a liquidity crisis, which ultimately leads to an increase in the cost of goods and a decrease business profitability and, accordingly, the financial stability of SMEs [8]. In this context, a number of economic indicators are discussed, without affecting the social sphere of functioning of SMEs as one of the components of the mechanism of regional development. That is why it is worth mentioning also the factors of production of medium and small business (availability of the most important resources for entrepreneurial activity: human capital; finance; developed infrastructure); in particular, a shortage of skilled labor in the labor market along with high lending rates and difficulties in collateral.

The deepest understanding of this mechanism is being explored by M.V. Melnichuk, S.V. Frumina. As the most important factor ensuring the effectiveness of the development of small and medium-sized businesses, the authors highlight the state regional programs in the field of SME support [9]. In our opinion, the real financial support from government programs in the field of SME development will ensure positive trends in ensuring the economic and social sustainability of the region. In addition, a number of researchers emphasize the ecological factor, through which the interaction between the quality of the environment and the economic growth of the region in the long term is determined [10-11]. Besides, as the researchers note, an increase in the level of environmental indicators in the region entails the development of new business areas for SMEs as priority suppliers of products and services [12-13].

Analyzing the existing factors that determine the relationship between the sustainability of the development of small and medium-sized enterprises and the regional component, the 
following groups of factors were identified, which, in our opinion, are important in the study of any region of the Russian Federation: 1) the economic and geographical position of the region; 2) state and regional support for small and medium-sized businesses; 3 ) labor resources; 4) demand for products and markets; 5) territorial tax benefits; 6) administrative barriers.

\subsection{Economic and geographical location}

Favorable economic and geographical position of the region, favorable climatic conditions, the availability of raw materials and natural resources, the development of transport infrastructure, etc. predetermine the degree of financial stability of enterprises employed in various industries. For example, the Yamalo-Nenets Autonomous District, the Astrakhan Region, the Irkutsk Region, and the Krasnoyarsk Territory are the main regions for gas production in the Russian Federation. We also note the diversified regions with a developed agro-industrial complex (Belgorod, Voronezh, Tambov regions), processing industrial activities (Sverdlovsk region, Perm, Krasnoyarsk territories). In addition to the availability of raw materials, there are leading regions with effective experience of interaction with large markets of the Russian Federation and the CIS countries (Moscow, St. Petersburg, Leningrad, Omsk, Tomsk, Novosibirsk, Vologda, Moscow regions, Khabarovsk Territory). The effective use of the favorable geographic location in the development of SMEs was facilitated by the support from the state authorities, which made it possible to reduce investment risks and effectively use human capital [14].

\subsection{State and regional support for SMEs}

Over the past 5 years, there has been a trend towards a reduction of government funding for small and medium-sized businesses, where subsidies to the budgets of the RF constituent entities amounted to 16.9 billion rubles in 2015; 2016 - 9.6 billion rubles; 2017 - 7.5 billion rub.; 2018 - 408.76 million rubles. However, in 2019, state support for small and mediumsized businesses in the regions of the country increased sharply by 1.6 times compared to 2015 , amounting to 27.18 billion rubles [15].

The state financial support for SMEs includes guarantees and sureties for loans, loans at low interest rates. So, in 2019 , the state planned to allocate 7.2 billion rubles to enterprises of the banking industry on concessional loans for representatives of SMEs, which was to significantly increase the size of subsidies for the concessional lending program in priority sectors.

With an increase in state financial support in the form of subsidies, loans at a low interest rate, a positive trend towards an increase in the income of SMEs has been revealed. Let's note that 2,306 thousand SMEs or $38.9 \%$ of the total number of SMEs in 2018 increased their income. The largest share of those who increased their income accounted for microenterprises $(2,180$ thousand SMEs or $94.6 \%)$, followed by small enterprises (117 thousand SMEs or $5.1 \%$, in the third place were medium-sized enterprises ( 8 thousand SMEs or $0.3 \%$ ) [16] In relation to the register as a whole, the majority of enterprises that increased their income belong to the sectors of health and social services $(45.4 \%)$, provision of other types of services $(44.8 \%)$ and trade (43.1 There are also various regional measures of financial support implemented through regional projects, in particular, the regional project "Expanding access of SMEs to financial support, including concessional financing", which contributes to the annual increase in the consolidated volume of financial support provided to small and medium business in the Belgorod region, the Komi Republic, the Kemerovo region, the Perm region and other regions. 


\subsection{Territorial tax incentives}

Changes in tax rates and insurance premiums are a nationwide factor, but regions in some cases have the right to establish certain preferential rates on a number of taxes. So, in the Sverdlovsk region, Resolution No. 321-PP, containing an increase in measures of tax support for SMEs in the region, where in relation to 18 types of economic activity, where the rate is $1 \%$ under the simplified taxation system and the rate of $1.1 \%$ on the property tax of organizations was adopted [17]. At the same time, this preferential measure applies to a number of other regions (Tyumen Oblast, Chechen Republic). In addition, some territories have a special tax regime of operation (TECD, free economic zones, etc.), which may also attract SMEs.

\subsection{Level of demand and purchasing power of the population}

This factor has a particularly acute impact on the functioning of SMEs in the constituent entities of the Russian Federation, where purchasing power is determined by the dynamics of household income and consumer prices. Thus, the ratio of average per capita money income (32.85 thousand rubles) to the size of the subsistence minimum on average per capita (11.47 thousand rubles) in the second quarter of 2020 reached a minimum over the last decade (from 2011 to 2020 .), amounting to $286.5 \%$ [18]. As a result, the current economic situation shows a low level of aggregate demand in the sectors. Small and medium-sized businesses have to work in unfavorable conditions due to rising inflation, deterioration of credit conditions for citizens, which leads to a significant decrease in their purchasing power. Stimulating the growth of the purchasing power of SMEs in the regions will be facilitated by entering larger domestic and international sales markets, in connection with which in 2019 small and medium-sized businesses received broader access to public procurement (the share of SME contracts in the total volume of purchases is $60 \%$ in terms of quantity indicator, $66 \%$ in amount).

\section{Conclusions}

1. Analysis of the existing methodological approaches to the factors that determine the sustainable development of SMEs in the region has shown the absence of a generally accepted classification and the assessment system in the context of the regional component.

2 . The author has highlighted the following regional factors of sustainable development of small and medium-sized businesses: a favorable economic and geographical position, which allows due to the availability of rich natural resources, the proximity to large markets to actively attract investment for its development; state and regional support for small and medium-sized businesses, carried out in the form of subsidies, concessional lending, which minimizes problems with finding sources of financing in the regions; territorial tax incentives; the decrease in the demand for purchasing power, which is caused by the increase in inflation due to the economic situation in the country, the decrease in real incomes of the population [19]. These factors undoubtedly significantly weight on the sustainable development and competitiveness of small and medium-sized enterprises in the context of the region, however, there are other factors, the analysis and assessment of which will be carried out in future studies.

3. In the context of dynamic economic development, it is expedient for "lagging regions" to adapt the positive experience of successful constituent entities of the Russian Federation (so-called "best practices") according to the proposed factors, which will 
improve the current situation of SMEs, thereby stimulating additional support from the state.

\section{References}

1. L. Condon, Austria. journal of environmen. educ., 20 (1), 57 (2004)

2. S. P. Zemtsov, V. L. Baburin, Reg. researches, 2, 4 (2019)

3. A.A. Savichev, Bulletin of the Univer, 4, 144 (2015)

4. A. A. Pleskov, Russ. Business, 2, 507 (2018)

5. B. Marileide, A. Juan, L. Ferreira, H. Denise, Jour. of Cleaner Production, 258 (2020)

6. A. B. Kharzinov, S. A. Makhosheva, S. V. Galachieva, Economic and legal issues, 30, 378 (2010)

7. M.O. Podprugin, Russ. Business, 13 (24), 214 (2012)

8. Strateg. for the development of small and medium-sized businesses in the Russ.Fed. for the period up to 2030 (2018)

9. M. V. Melnichuk, S. V. Frumina, Region. economy and manag.: elect. sci. jour., 4 (52), 1 (2017)

10. M. Gallardo-Vázquez, Business Research Quarterly, 17 (2), 115 (2014)

11. D. E. Tolmachev, E. A. Ulyanova, L. M. Pliner, New Research into Regional Economy Problems, 1, 79 (2015)

12. Greening small and medium-sized enterprises, 80 (2015)

13. R. Bucea-Manea-Tonis, Jour. of economic development, environment and people, 4, 41 (2015)

14. S. P. Zemtsov, Yu.A. Smelov, Jour.of the New economic Associat., 4 (40), 84 (2018)

15. National proj. «Small and medium-sized businesses and support for individual entrepreneurship» (2019)

16. Report on the results of research on the structure and dynamics of growth of small and medium-sized businesses (2019)

17. Resolution Of the government of the Sverdlovsk region of 21.05.2020, 321 (2020)

18. Rosstat, $87(2019,2020)$

19. P. Salimzadeh, J. A. Courvisanos, Jour. of Environmental Assessment Policy and Management, 17, 4 (2015) 